\title{
Causes of polytrophism of three lakes in the Wdzydze Landscape Park
}

\author{
Jerzy Jańczak, Wojciech Maślanka, Kamil Nowiński \\ University of Gdańsk, Institute of Geography, Department of Lakelands Geography, Bażyńskiego 4, 80-952 Gdańsk, Poland, \\ e-mail: geojj@univ.gda.pl,bgiowm@univ.gda.pl,geokamil@univ.gda.pl
}

\begin{abstract}
In the lakes Cheb and Słupino, located in the Wdzydze Landscape Park the quality of waters has been deteriorating in recent years. In the hydrologic year 2009 the quality of water was examined three times. Monthly measurements on the lake inflows and outflows were carried out 12 times to determine biogenic loads. In 2010 the supplementary measurements of biogenic loads were taken in the streams five times. According to Vollenweider's criterion, the loads of nitrogen and phosphorus compounds are too big, the heaviest to Lake Cheb. The discharge from the new sewage treatment plant is directed by the inflows into this lake. A similar situation takes place in the inflow to Lake Schodno. Paradoxically, in some catchments the construction of the sewage treatment plant may result in the deterioration of lake water quality.
\end{abstract}

Key words: limnology, lake eutrophication, biogenic load, Wdzydze Landscape Park

\section{Introduction}

Lakes, especially smaller ones, are particularly susceptible to the deterioration of their water quality. Such processes were intensified in the second half of the twentieth century, mainly as a result of inappropriate management. Fortunately the current situation is gradually improving because the rules of environmental protection are being observed considerably more. Among others, the creation of national and landscape parks in the particularly valuable areas has become one of the forms of environmental protection. However, it is not enough. The three lakes that are the study subjects in this paper are not located within the borders of any landscape park. Despite tightened rules and forms of area management there, water quality in these lakes was noted several years ago to be deteriorating. The authors try to present the causes of this phenomenon. Paradoxically, this situation may result from the construction of a sewage treatment plant.

\section{Study area and research methods}

The lakes are located in the area of the Wdzydze Landscape Park (Fig. 1). The basic morphometric data of the lakes are shown in Table 1.

The objective of the research was to examine water quality in the lakes, and principally, to determine biogenic loads - phosphorus and nitrogen compounds that inflow from the catchment through permanent streams. The measurement points are presented in Fig. 1. Three measurement stands were located in the max. depth of the lakes. Seven points were located on the inflows and outflows. The fundamental examinations were carried out in the hydrologic year 2009. The measurements on the lakes were taken three times (on 11th May, 26th June, and on 6th September). Meanwhile, the streams were measured every month. In 2010 they were examined five times.

Water quality was defined by two methods: Carlson's method (Table 2) and the method prepared 


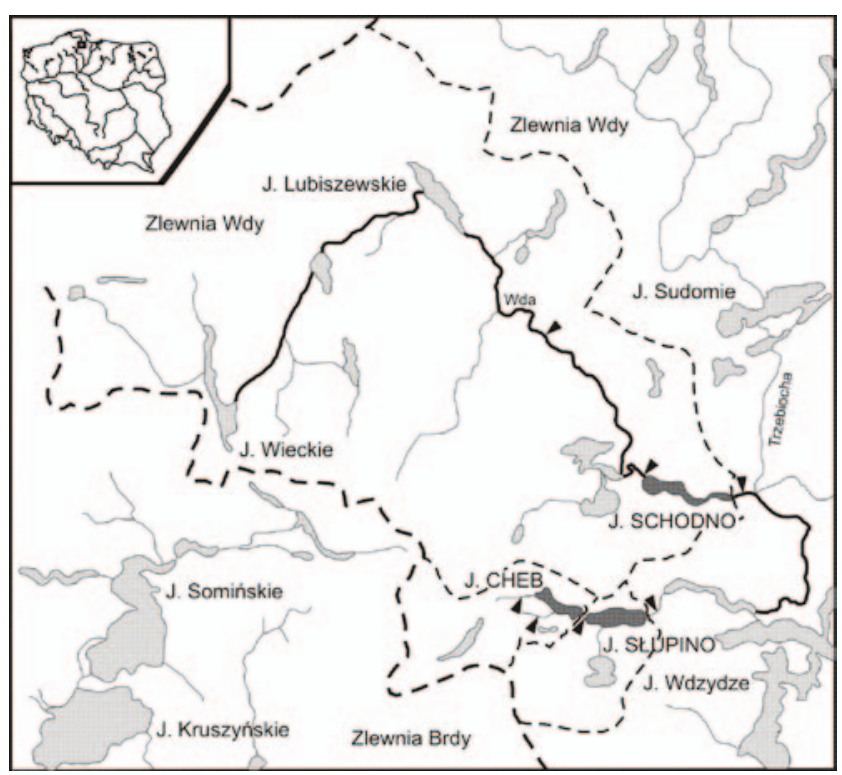

Fig. 1. Studied lakes and measurement points at the inflows and outflows

according to the recommendations included in the EU Water Framework Directive 2000 (Jańczak 2004; Jańczak 2007). The latter accounts for seven indices (Table 3). The lake class is determined by the bonitation method, which awards as many points to each index as the water class is according to a given index: from 1 (class I) to 5 (class V). The oxygenation index is ignored in the case of the lakes with the mean depth below $3 \mathrm{~m}$. Apart from that, as far as visibility and chlorophyll are concerned, the mean and minimum values (for visibility) and the maximum value (for chlorophyll) are taken into account. If these values are found in different classes, the mean value of these two classes is taken. In order to determine the general class of lake water quality, the mean value of all the indices is calculated, and then the lake is classified according to the following rule: high class (I) < $1.5 p t$., good class (II) 1.51-2.5pt., moderate class (III) 2.51-3.5pt., poor class (IV) 3.51-4.25pt., and bad class $(\mathrm{V})>4.25 \mathrm{pt}$. However, if the mean yearly visibility is lower than $0.5 \mathrm{~m}$, or proves to be lower than $0.3 \mathrm{~m}$, the index is treated as a verifying one, and thus disqualifies the lake down to the bad class (V).

In the hydrologic year 2010 only measurements to determine biogenic loads in the streams were conducted. They were carried out five times: in November, January, April, June and August.

\section{Results}

According to Carlson's method (Table 2), the mean index exceeds 60 for all the lakes, which means these are eutrophic lakes. Lake Cheb is of the worst water quality. According to the five-degree classification (Table 3), Lake Schodno (the mean index 3.42) and Lake Słupino (the mean index 3.28), stay within the moderate class (III), whereas, Lake Cheb shows the mean index of 4.17 , so this would still make the poor class (IV). However, the mean value of the visibility index is lower than $0.5 \mathrm{~m}$, which, according to the assumptions of the method, should disqualify the lake down to the bad class (V). Undoubtedly, this lake is of the worst water quality compared to the others.

Table 1. Morphometric data of the lakes

\begin{tabular}{|c|c|c|c|c|c|}
\hline \multirow{2}{*}{ Lake } & \multirow{2}{*}{ Lake area [ha] } & \multirow{2}{*}{ Volume $\left[\mathrm{hm}^{3}\right]$} & \multicolumn{2}{|c|}{ Depth [m] } & \multirow{2}{*}{$\begin{array}{c}\text { Catchment area } \\
{\left[\mathrm{km}^{2}\right]}\end{array}$} \\
\hline & & & $\max$. & mean & \\
\hline Schodno & 50 & 1.4 & 5.2 & 2.8 & 173.8 \\
\hline Cheb & 32 & 0.7 & 5.5 & 2.1 & 11.9 \\
\hline Słupino & 62 & 4.4 & 22.5 & 7.1 & 22.3 \\
\hline
\end{tabular}

Table 2. Trophic state indices according to Carlson's classification

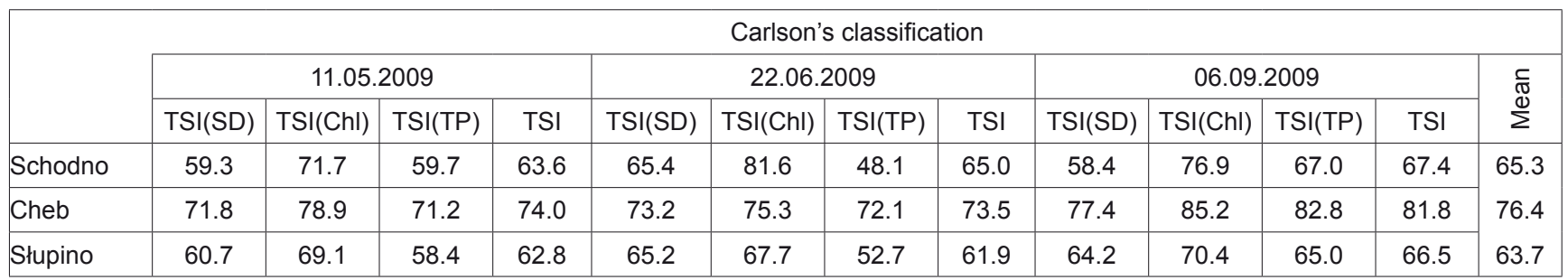


Table 3. Water quality of the lakes in the classes

\begin{tabular}{|c|c|c|c|c|c|c|c|}
\hline \multirow{2}{*}{ Index } & \multirow{2}{*}{ Unit } & \multicolumn{5}{|c|}{ Water quality } & \\
\hline & & high & good & moderate & poor & bad & \\
\hline $\begin{array}{l}\text { Mean oxygen saturation } \\
\text { of the hypolimnion }\end{array}$ & $\%$ & $>40$ & $\leq 40>20$ & $\leq 20>10$ & $\leq 10>5$ & $\leq 5$ & \\
\hline Słupino & & & & 10.3 & & & 3 \\
\hline Oxygen above the bottom & $\mathrm{mg} \mathrm{dm} \mathrm{dm}^{-3}$ & $>5$ & $\leq 5>4$ & $\leq 4>2$ & $\leq 2>1$ & $\leq 1$ & \\
\hline Schodno, Cheb & & \multicolumn{5}{|c|}{ The lakes with the mean depth below $3 \mathrm{~m}$} & \\
\hline Total phosphorus & $\mathrm{mg} \mathrm{dm} \mathrm{dm}^{-3}$ & $\leq 0.01$ & $>0.01 \leq 0.05$ & $>0.05 \leq 0.1$ & $>0.1 \leq 0.2$ & $>0.2$ & \\
\hline Schodno & & & 0.050 & & & & 2 \\
\hline Cheb & & & & & 0.150 & & 4 \\
\hline Słupino & & & 0.050 & & & & 2 \\
\hline Total nitrogen & $\mathrm{mg} \mathrm{dm}{ }^{-3}$ & $\leq .05$ & $>0.5 \leq 1.0$ & $>1.0 \leq 2.0$ & $>2.0 \leq 3.0$ & $>3.0$ & \\
\hline Schodno & & & 0.640 & & & & 2 \\
\hline Cheb & & & & 1.580 & & & 3 \\
\hline Słupino & & & 0.853 & & & & 2 \\
\hline Mean year visibility & $\mathrm{m}$ & $>6$ & $\leq 6.0>4.0$ & $\leq 4.0>2.0$ & $\leq 2.0>1.0$ & $<1.0$ & \\
\hline Schodno & & & & & & 0.95 & 4.5 \\
\hline Cheb & & & & & & 0.40 & 5 \\
\hline Słupino & & & & & & 0.80 & 4.5 \\
\hline Minimum visibility & $\mathrm{m}$ & $>4$ & $\leq 4.0>2.0$ & $\leq 2.0>1.0$ & $\leq 1.0>0.5$ & $<0.5$ & \\
\hline Schodno & & & & & 0.7 & & \\
\hline Cheb & & & & & & 0.3 & \\
\hline Słupino & & & & & 0.7 & & \\
\hline Mean year chlorophyll & $\mathrm{mg} \mathrm{m}^{-3}$ & $\leq 5.0$ & $>5.0 \leq 10.0$ & $>10.0 \leq 20.0$ & $>20.0 \leq 30.0$ & $>30.0$ & \\
\hline Schodno & & & & & & 51 & 5 \\
\hline Cheb & & & & & & 49 & 5 \\
\hline Słupino & & & & & 21 & & 3.5 \\
\hline Maximum chlorophyll & $\mathrm{mg} \mathrm{m}^{-3}$ & $\leq 10.0$ & $>10.0 \leq 20.0$ & $>20.0 \leq 30.0$ & $>30.0 \leq 60.0$ & $>60.0$ & \\
\hline Schodno & & & & & & 78 & \\
\hline Cheb & & & & & & 62 & \\
\hline Słupino & & & & 23 & & & \\
\hline $\mathrm{pH}$ & & $6.7-7.2$ & 7.3-7.7 & $7.2-8.2$ & $8.3-8.7$ & $>8.7$ & \\
\hline & & & $6.6-6.2$ & $6.1-5.7$ & $5.6-5.2$ & $>5.2$ & \\
\hline Schodno & & & & & 8.60 & & 4 \\
\hline Cheb & & & & & & 9.00 & 5 \\
\hline Słupino & & & & & & 8.73 & 5 \\
\hline Conductivity & $\mu \mathrm{S} \mathrm{cm} \mathrm{cm}^{-1}$ & $<100.0$ & $100.0-200.0$ & $200.0-400.0$ & $400.0-500.0$ & $>500.0$ & \\
\hline Schodno & & & & 303 & & & 3 \\
\hline Cheb & & & & 293 & & & 3 \\
\hline Słupino & & & & 362 & & & 3 \\
\hline
\end{tabular}

The norms for the indices in the classes are marked in bold.

Other explanations in the text.

Apart from visibility, the mean value of $\mathrm{pH}$, which is 9, should draw attention. This may result from intense photosynthesis of phytoplankton. However, the mean and maximum chlorophyll content in Lake Cheb is slightly lower than in Lake Schodno. This may result from the fact that light acts as a limiting agent, and algae are not able to flourish any more. This conclusion is proven by the $90 \%$ share of mineral phosphorus in the total phosphorus which can be found in this lake. In the other lakes the proportion of mineral phospho- 
rus in the total phosphorus is also high; it exceeds $40 \%$ in Lake Schodno, and is $60 \%$ in Lake Słupino. This may possibly result from the fact that the general content of phosphorus and nitrogen in these lake waters is relatively low. These indices are found in the waters of two lakes at the level of the good class (Table 2). Lake Słupino is a stratified lake, in which there was no oxygen during the summer in the lower part of the hypolimnion, from approximately $12 \mathrm{~m}$. Shallow lakes Schodno and Cheb are generally well oxygenated as periodically they get mixed down to the bottom. They might lack oxygen in the near-bottom layers during the long-lasting windless and hot weather.

The inflow and outflow of nitrogen and phosphorus compounds attract particular attention as they mainly affect lake eutrophication. The studied lakes belong to two hydrographical systems. Lake Schodno has a big catchment, and the River Wda runs through it. However, two smaller streams inflow into Lake Cheb. Its outflow directly supplies Lake Słupino. There were two measurement points on the River Wda, one directly at the lake and the other several kilometres upstream (Fig. 1). There is a discharge from the Libusz sewage treatment plant not so far away from it. The comparison of the loads at the two measurement points leads to a conclusion about its potential influence upon the supply of the lake with biogenes.

The results of the measurements of phosphorus and nitrogen loads are shown in Table 3 and 4. Lake Schodno took in $45200 \mathrm{~kg} \mathrm{~N}$. The load was considerably smaller at the point in Lipusz, and amounted to $28000 \mathrm{~kg}$. $49400 \mathrm{~kg} \mathrm{~N}$ flowed out of the lake, that is approximately $9 \%$ more than flowed into it. In the first half of the hydrologic year the loads were higher in general. As for the load of phosphorus it amounted to $1750 \mathrm{~kg} \mathrm{P}$ at the point in Lipusz, $2219 \mathrm{~kg} \mathrm{P}$ at the lake, and $2991 \mathrm{~kg} \mathrm{P}$ at the outflow.

Similarly, in the case of phosphorus the inflowing loads in the first half of the year were slightly bigger. The load at the outflow was considerably bigger than at the inflow, which proves a substantial internal supply. It is rather unlikely that such a load could be supplied from the direct catchment as it is strongly influenced by anthropopressure. The critical load of phosphorus for this lake amounts to $2.26 \mathrm{~g} \mathrm{~m}^{-2} \mathrm{yr}^{-1}$ according to Vollenweider's criterion. The measured real load amounted to $3.58 \mathrm{~g} \mathrm{~m}^{-2} \mathrm{yr}^{-1}$. Thus, the critical load was exceeded approx. 1.6 times.

Lake Cheb is supplied by two streams into one of which the discharge of "purified" sewage from the Parowa sewage treatment plant has been directed. In $20091261 \mathrm{~kg} \mathrm{~N}$ flowed into Lake Cheb and $6162 \mathrm{~kg}$ $\mathrm{N}$ left it; that is almost five times more. The structure of the inflowing nitrogen is dominated by mineral nitrogen. In particular months the inflow of nitrogen was not varied. Yet the most powerful outflow was in the summer months, and organic nitrogen dominated. However, the weight of mineral nitrogen was the same at the inflow as at the outflow. As for phosphorus, Lake Cheb took in $409 \mathrm{~kg}$ P. $549 \mathrm{~kg}$ P left the lake, that is approximately $35 \%$ more. According to Vollenweider's criterion, the critical load of phosphorus amounts to $0.36 \mathrm{~g} \mathrm{~m}^{-2} \mathrm{yr}^{-1}$. The real load amounted to $1.28 \mathrm{~g}$ $\mathrm{m}^{-2} \mathrm{yr}^{-1}$, and exceeded the critical load by approx. 3.5 times.

The outflowing loads run directly to Lake Słupino. $7540 \mathrm{~kg}$ of nitrogen and $480 \mathrm{~kg}$ of phosphorus flowed out of Słupino. In 2009 that was the only example of load reduction recorded with respect to the studied lakes.

Mineral phosphorus constituted approx. 60\% in the yearly load, both in the inflow and in the outflow. However, in the summer months the proportion was small as it was used up by autotrophs in the process of primary production. According to Vollenweider's criterion, the critical load of phosphorus for Lake Słupino amounts to $0.38 \mathrm{~g} \mathrm{~m}^{-2} \mathrm{yr}^{-1}$. The real load was $0.88 \mathrm{~g} \mathrm{~m}^{-2} \mathrm{yr}^{-1}$, thus the critical load was exceeded by approx. 2.3 times.

There were fewer measurements of biogenic load in 2010. It was examined five times within that year. It is worthwhile mentioning that less nitrogen

Table 4. The inflow and outflow of nitrogen and phosphorus compounds to Lake Schodno

\begin{tabular}{|c|c|c|c|c|c|c|}
\hline \multirow{3}{*}{ Biogenic substances } & \multicolumn{2}{|c|}{ Town of Lipusz } & \multicolumn{2}{|c|}{ Inflow } & \multicolumn{2}{|c|}{ Outflow } \\
\hline & \multicolumn{2}{|c|}{$\left[\mathrm{kg} \mathrm{yr}^{-1}\right]$} & \multicolumn{2}{|c|}{$\left[\mathrm{kg} \mathrm{yr}^{-1}\right]$} & \multicolumn{2}{|c|}{$\left[\mathrm{kg} \mathrm{yr}^{-1}\right]$} \\
\hline & yr 2009 & yr 2010 & yr 2009 & yr 2010 & yr 2009 & yr 2010 \\
\hline Nitrogen & 28000 & 24650 & 45200 & 28700 & 49400 & 24700 \\
\hline Phosphorus & 1750 & 2299 & 2219 & 2902 & 2991 & 2344 \\
\hline
\end{tabular}


flowed into Lake Schodno than in the previous year. Even less flowed out of it (Table 4). It was different with the phosphorus load. More of it flowed into the lake and less flowed out of it. Moreover, in the two years the role of Lake Schodno in load transformation was different. In 2009 the lake raised both the load of nitrogen and phosphorous. In contrast, in 2010 the loads of two biogenes declined in the lake.

Changes also took place in the Cheb - Słupino lake system in 2010 (Table 5). The inflow and outflow of nitrogen in Lake Cheb were slightly smaller. However, more phosphorus flowed into it and out of it. The function of Lake Cheb did not change, however. In those two years the loads increased. Less nitrogen flowed out of Lake Słupino, and the load of outflowing phosphorus was the same. The transformational role of Lake Słupino also changed partially. In 2009 the lake augmented the nitrogen load, and reduced the phosphorus load. In 2010 the load of two biogenes reduced.

\section{Discussion}

The deterioration of water quality in the lakes located in the landscape park must arouse particular anxiety. Especially if there is suspicion that deterioration may result from anthropogenic activity. The primary objective of a landscape park is the preservation and even improvement of natural amenities that can be found in such a park (Act Reg. RP 1991. No. 114, pos. 492). The preservation of these amenities should be carried out in the conditions of a rational economic activity. There is, however, no precise definition of what is meant by a rational economic activity. Surely it should include the construction of a sewage treatment plant. Yet is the location of the Parowa sewage treatment plant in the close vicinity of the Park an example of a rational economic activity? The discharge from the plant is directed to a small stream which supplies Lake Cheb. Undoubtedly, the sewage treatment plant was located there according to the regulations.
However, these regulations may be too generalized. They do not account for the specificity of a particular hydrographical situation. Lake Cheb is too small to manage such a big load of biogenes. This could have been predicted earlier by conducting appropriate estimates. Perhaps not observing the norms of the maximum loads of phosphorus and nitrogen which are discharged from the treatment plant may be the underlying cause?

Lake Cheb supplies Lake Słupino with its waters. Lake Słupino supplies Lake Słupinko, and afterwards waters outflow to a big lake, Lake Wdzydze. The lakes together with their joining river sections constitute a fluvio-lacustrine system. Such systems are very numerous in the Polish lakelands. They have become a subject of more detailed analyses only recently, especially in the context of their role in the transformation of biogenic loads (Hillbricht-Ilkowska 1994; HillbrichIlkowska and Kostrzewska-Szlakowska 1996; Kufel 1996; Kajak 1998; Gołdyn 2000; Bajkiewicz-Grabowska 2002; Bajkiewicz-Grabowska and Zdanowski 2006; Lossow et al. 2006; Jańczak et al. 2007; Bogdanowicz and Cysewski 2008; Zdanowski et al. 2009).

As is often the case with science, the more precisely a problem is examined, the more questions are asked than answered. It is generally known that some lakes mainly play a transit role, others reduce, and still others augment the load. Without more thorough studies this load is difficult to separate from the area supply (Niemirycz et al. 1993; Taylor et al. 1997; Bogdanowicz 2004). Some lakes may perform the same functions for a long time. This depends upon the hydrological specificity of a particular system and lake morphometry (Bajkiewicz-Grabowska 2002). Some lakes may serve various functions in different years, depending upon changeable hydro-meteorological conditions. These conditions have an influence upon the amount of water, and the matter supplied into the lakes from the catchment and its circulation within the lake ecosystems. These processes run in a different way in bigger and smaller lakes, and in stratified and

Table 5. The inflow and outflow of nitrogen and phosphorus compounds to the lakes: Cheb and Słupino

\begin{tabular}{|l|c|c|c|c|c|c|}
\hline \multirow{2}{*}{ Biogenic substances } & \multicolumn{2}{|c|}{ Cheb inflow } & \multicolumn{2}{c|}{$\begin{array}{c}\text { Cheb outflow } \\
\text { Słupino inflow }\end{array}$} \\
\cline { 2 - 7 } & \multicolumn{2}{|c|}{$\left[\mathrm{kg} \mathrm{yr}^{-1}\right]$} & \multicolumn{2}{|c|}{$\left[\mathrm{kg} \mathrm{yr}^{-1}\right]$} & \multicolumn{3}{c|}{ Słupino outflow } \\
\cline { 2 - 7 } & $\mathrm{yr} 2009$ & $\mathrm{yr} 2010$ & $\mathrm{yr} 2009$ & $\mathrm{yr} 2010$ & $\mathrm{yr} 2009$ & $\mathrm{yr} 2010$ \\
\hline Nitrogen & 1261 & 1080 & 6162 & 8002 & 450 & 480 \\
\hline Phosphorus & 409 & 766 & 549 & 886 & 480 \\
\hline
\end{tabular}


polymictic lakes. Depending upon oxygen conditions, the role of internal supply from the bottom deposits is particularly significant (Kajak 1998; Jańczak 1997; Tórz and Nędzarek 2009; Pyka et al. 2009). In the discussed situation, Lake Cheb constantly augments the load of phosphorus and nitrogen. Its ecosystem is not able to manage such a large supply of biogenes, which is mainly brought in from the sewage treatment plant.

It may be assumed theoretically that in most cases the bigger the lake the bigger role in the transformation of biogenes the lake should play. However, the location of the lake in the fluvio-lacustrine system is also of importance here. The discussed lakes are rather small. In the river-lake system (the inflow to Lake Cheb - Lake Cheb - Lake Słupino - the outflow from Lake Słupino) the lakes play a significant role. They are located in the upper part of the local catchment. A considerable load of biogenes reaches them and is significantly transformed by them. The biggest differences occur in total phosphorus load at the inflow and outflow of Lake Cheb. Nitrogen load is increased in the lake up to as much as $490-550 \%$. Mineral nitrogen clearly dominates at the inflow, whereas organic nitrogen dominates at the outflow. Such a structure proves artificial feeding and considerable primary production in the lake. The composition of the phosphorus load, in which phosphates constitute $90 \%$, points to the sewage treatment plant. Total phosphorus load in the lake is augmented up to approx. $115-135 \%$. In the outflow mineral phosphorus constituted approx. $60 \%$, which is aconsiderable amount. The outflowing load flows directly to Lake Słupino. Between the two lakes there is an approximately 500 -metre river section. In Lake Słupino the nitrogen load rose up to approx. $120 \%$, and in the second year declined down to $75 \%$. On the other hand the phosphorus load reduced within the range $54-87 \%$.

In 2009 Lake Schodno augmented the load of both nitrogen and phosphorus. The increase in the nitrogen load was still rather small (approx. 109\%), whereas the phosphorus load was increased to approx. $135 \%$. The percentage increase in the phosphorus load was the same as in Lake Cheb. However, a considerably bigger amount of water - approx. $34.4 \mathrm{hm}^{3} \mathrm{yr}^{-1}$ ran through Lake Schodno in 2009, while $4.95 \mathrm{hm}^{3} \mathrm{yr}^{-1}$ flowed through lake Cheb, and $6.3 \mathrm{hm}^{3} \mathrm{yr}^{-1}$ through Lake Słupino. Water is exchanged approx. 25 times per year in Lake Schodno, and approx. 7 times per year in Lake Cheb, and approx. 1.5 times per year in Lake Słupino. In 2010 the function of Lake Schodno was reversed. The lake reduced the nitrogen load down to approx. $86 \%$, and phosphorus down to approx. $81 \%$. The role of the lakes is different in every system. Considerable exchange of water in Lake Schodnomeans that the critical load measured by Vollenweider's criterion may be considerably bigger for this lake, and its retention time very short. In Lake Cheb and Słupino the critical load is smaller by far, similar in those two lakes. The retention time is longer, particularly in Lake Słupino. The importance of Lake Schodno in the transformation of the load flowing through it is smaller than that of Lake Cheb. And there is no other lake in the close vicinity of Lake Schodno, while directly after Lake Cheb there is Lake Słupino, and then other lakes.

The Parowa sewage treatment plant plays a decisive role in the polytrophication of Lake Cheb. If the load discharged from it is not restrained the lake will be degraded completely. Constant loading with excessive amounts of nutrients will have more influence upon Lake Słupino, which will also be endangered with hypertrophy. Lake Słupino is stratified, and a considerable portion of nitrogen and phosphorus accumulated in the deposits cannot get through to the epilimnion during the summer months. Therefore, it still shows a positive balance of total phosphorus; more phosphorus inflows into it than outflows from it. There is no data concerning the balance of biogenes in the studied lakes from the earlier period. That is why it is impossible to compare what load of biogenes had flowed into them before two sewage treatment plants were constructed. The Park workers claim that water began to worsen visually after they had started to operate. There are no other potential sources of pollutants in the catchments of these lakes. The sewage treatment plant in Lipusz on the Wda may have played a part in the deterioration of water quality in Lake Schodno to a certain degree, probably not too small. The decline in water transparency in this lake may be a cause of the disappearance of the pike, which used to be very numerous in this lake.

Sewage treatment plants should be constructed, yet their influence upon waters into which the treated sewage will be directed should be analysed more accurately. The lakes located in the lakelands of Northern Poland should attract particular attention. Paradoxically, the construction of sewage treatment plants may cause deterioration of lake water quality. 


\section{Conclusion}

- Water quality in the studied lakes is poor or even bad. Lake Cheb is in the worst condition.

- The inflow of biogenic loads to the lakes is too big and exceeds the critical index according to Vollenweider's criterion.

- The composition of the load is dominated by phosphates and nitrates. The load mainly comes from the discharge of waters from the two new sewage treatment plants.

\section{References}

Bajkiewicz-Grabowska E., 2002, Obieg materii w systemach rzeczno-jeziornych (Circulation of matter in the riverlake systems), Wyd. UW, Warszawa, p. 274.

Bajkiewicz-Grabowska E., Zdanowski B., 2006, Phosphorus retention in lake sections of Struga Siedmiu Jezior, Limnol. Rev. 6: 5-12.

Bogdanowicz R., 2004, Hydrologiczne uwarunkowania transportu wybranych związków azotu i fosforu Odrą i Wisłą oraz rzekami Przymorza do Bałtyku (Hydrological factors influencing transport of selected nitrogen and phosphorus compounds from the Odra River, the Vistula River and Polish coastal rivers to Baltic Sea), Wyd. UG. Gdańsk, p. 160.

Bogdanowicz R., Cysewski A. 2008, Transformation of riverine nutrients load in selected lakes of the Zaborski Landscape Park, Limnol. Rev. 8(1-2): 13-19.

Carlson R. E., 1977, A trophic state index for lakes, Limnol. Oceanogr. 22 (2): 361-369.

Gołdyn R., 2000, Zmiany biologicznych i fizyczno-chemicznych cech jakości wody rzecznej pod wpływem piętrzenia we wstępnych nizinnych zbiornikach zaporowych (Changes in biological and physico-chemical parameters of river water quality as a result of its damming in preliminary lowland reservoirs, Wyd. Nauk. UAM, Poznań, p. 185.

Hillbricht-Ilkowska A., 1994, Ocena ładunku fosforu i stanu zagrożenia jezior Suwalskiego Parku Krajobrazowego oraz niektóre zależności pomiędzy ładunkiem a wskaźnikiem trofii jezior (Evaluation of the phosphorus load, and degree of endangerment, of lakes in Suwałki Landscape Park, and some relationships between the load and indices of the trophic status of lakes), Zesz. Nauk. Kom. PAN „Człowiek i Środowisko” 7: 201 - 214.

Hillbrich-Ilkowska A., Kostrzewska-Szlakowska J., 1996, Ocena ładunku fosforu i stan zagrożenia jezior rzeki Krutyni (Pojezierze Mazurskie) oraz zależność między ładunkiem a stężeniem fosforu w jeziorach (Estimation of the phosphorus load and degree of endangerment of lakes along the River Krutynia (Mazurian Lakeland), as well as of the relationship between the load and the inlake concentration of phosphorus), Zesz. Nauk. Kom. PAN „Człowiek i Środowisko”13: 97-123.
Jańczak J., 1997, Zmiany jakości wody jezior na podstawie badań prowadzonych w monitoringu reperowym jezior polskich w latach 1991-1995 (Changes in water quality of lakes on the bases of watermark monitoring studies of Polish Lakes in the years 1991-1995), Bibl. Monit. Środ., PIOŚ, Warszawa, p. 116.

Jańczak J., 2004, Proposal of new methodology of monitoring on Polish lakes, Limnol. Rev. 4: 101-106.

Jańczak J., 2007, Jakość wody (Water quality), [in:] Borowiak D. (ed.), Jeziora Kaszubskiego Parku Krajobrazowego (Lakes of the Kashubian Landscape Park), Bad. Limnol. 5, Gdańsk: 267-278.

Jańczak J., Maślanka W., Nowiński K., 2007, The impact of selected Pomerania lakes on nutrient load transformation. Limn. Rev. 7(4): 187-193.

Kajak Z., 1998, Hydrobiologia-Limnologia (Hydrobiology-Limnology), PWN, Warszawa, p. 355.

Kufel L., 1996, Analiza przemian i retencji związków azotu i fosforu w małym układzie rzeczno-jeziornym (zlewnia rzeki Krutyni, Pojezierze Mazurskie) (Analysis of transformations and retention of nitrogen and phosphorus compounds in a small river-lake system of the Krutynia drainage basin (Mazurian Lakeland)), Zesz. Nauk. Kom. PAN „Człowiek i Środowisko”13: 225-236.

Lossow K., Gawrońska H., Łopata M., Teodorowicz M., 2006, Role of lakes in phosphorus and nitrogen transfer in the river-lake system of the Mrózka and upper Łyna rivers, Limnol. Rev. 6: 171-178.

Niemirycz E., Taylor R., Makowski Z., 1993, Zagrożenie substancjami biogennymi wód powierzchniowych $(\mathrm{Nu}-$ trient threat to surface waters quality), Bibl. Monitor. Środ., PIOŚ, Warszawa, p. 90.

Pyka J.P., Zdanowski B., Stawecki K., Prusik S., 2009, Trends in environmental changes in the selected lakes of the Mazury and Suwałki Lakelands, Limnol. Rev. 9(2) :101109.

Taylor R., Bogacka T., Makowski Z., 1997, Emisja azotu i fosforu $\mathrm{z}$ obszaru Polski do wód powierzchniowych (Emission of nitrogen and phosphorus from the area of Poland to surface waters), Wiad. IMGW 3: 3-21.

Tórz A., Nędzarek A., 2009, The nitrogen and Phosphorus cycles At the Żeglica Lake waters (Międzyodrze, West Pomeranian region), Limnol. Rev. 9(1): 27-38.

Vollenweider R. A., 1976, Advances in defining critical loading levels for phosphorus in lake eutrophication, Mem. Inst. Ital. Idrobiol. 33: 53-83.

Zdanowski B., Wołos A., Wierzchowska M., 2009, Change patterns in the trophic state of Lake Mamry Północne and Lake Niegocin (Mazurian Lake District, Poland), Limnol. Rev. 9(1): 39-60. 